engine now in production. This engine, known as the Pegasus $\mathrm{X}$, gives an output of 920 horse-power at ground-level, and maintains 875 horse-power at $6,000 \mathrm{ft}$. altitude, with a remarkable weight of only $995 \mathrm{lb}$., completely equipped. This figure of $1.08 \mathrm{lb}$. per H.P. is the least weight/power ratio ever reached in a production type of aero engine, designed to stand up to the conditions of everyday use. The Rolls-Royce racing engine produced for the last Schneider Trophy race had a ratio of only $0.7 \mathrm{lb}$. per H.P., but this was not a production type. The fuel consumption of the Pegasus $\mathrm{X}$ is also as good as any other type in existence; earlier air-cooled engines compared badly with contemporary liquidcooled types in this respect. It also standardises a controllable pitch airscrew, carrying the fittings for the hydraulic control gear integral with itself. It is interesting to note the progress in weight reduction in aero engine practice since the adaptation of the internal combustion engine to flying requirements. In 1903 the Wright Bros. original engine weighed $12.7 \mathrm{lb}$. per H.P. In 1913 the average was about $4.9 \mathrm{lb}$., while during the War period, 1914-18, rotary engines were produced as low as $2 \cdot 5 \mathrm{lb}$. The lowest weight to-day, previous to the new Bristol engine, was $1 \cdot 15 \mathrm{lb}$. per H.P.

\section{Increase of Power Output in Aeroplanes}

SCIENCE Service, of Washington, D.C., reports that, in future, U.S. Army aeroplanes will be delivering approximately 70 per cent more power per pound of gasoline than was the case seven years ago. In 1928 an increase of 33 per cent in power output was obtained by alteration of engine design to utilise 92 instead of 50 octane gasoline; and now a further increase is envisaged by the substitution of special lead blended iso-octane for the 92 octane gasoline. Petroleum will still be used as a raw material in the production of this fuel, but the molecules will be 'torn down' and 'rebuilt' into new fuels. The com. position of such fuels will be half iso-octane, which is now being manufactured in substantial quantities by several refineries, and half good quality ordinary aviation spirit with the addition of 'ethyl'. The cost per gallon of the final product will be higher than that of present aviation fuels, but since its power per pound is greater it ought in the long run to prove more economical. The practical result of its utilisation will be to enable aeroplanes to fly farther and faster without increasing the weight of fuel carried.

\section{Parliamentary Science Committee}

A meeting of the general committee of the Parliamentary Science Committee was held at the House of Commons on May 14, Sir Arnold Wilson in the chair. It was reported that recent accessions to the list of bodies allied to the Committee include the Institution of Civil Engineers, the Institute of Chemistry and the National Veterinary Medical Association. In the period reviewed in the Honorary Secretary's report, special mention was made of the Committee's successful efforts to secure consideration of the claims of scientific research in connexion with the Metropolitan Water Board Bill now before Parliament. Other activities reported included certain aspects of the Government of India Bill, the exemption from income tax of funds expended on industrial research, and the claims of science and technology to representation in the higher administrative posts in Government service. Sir Arnold Wilson addressed the Committee and in his concluding remarks said : "It will take time to evolve a suitable mechanism and a live organisation, but, if sufficient support is forthcoming and the membership widened to cover science as a whole, there is no reason why we should not be of real use and value to the nation; for it is in Parliament, and nowhere else, that the balance between science and ethics has to be settled, day by day, in terms of statutes and regulations".

\section{British Postgraduate Medical School}

H.M. THE KrNG formerly opened the British Postgraduate Medical School at the L.C.C. Hospital, Ducane Road, Hammersmith, on May 13. It will be recalled that the School arose out of a recommendation of a committee under the Earl of Athlone that London should have a centre for medical post. graduate work comparable with the great continental medical schools, which should be attached to the University and receive substantial Government support. By the co-operation of the Government, the University of London and the London County Council, one of the hospitals under the last-mentioned body was allocated and specially enlarged and equipped for the purpose (see NAture, April 21, 1934, p. 600). Their Majesties were received by Sir Austen Chamberlain, chairman of the governing body of the School, who described its inception, stating that the School has three great tasks : to enable general practitioners to become familiar with the latest developments in diagnosis and treatment; to provide instruction for graduates undertaking specialist studies; and to promote research and advance medical knowledge. The King, in his reply, said that "The provision within the University of London of a new centre for clinical teaching marks a notable advance in the continuous effort of the medical profession to increase its capacity for service to mankind". He concluded by expressing the hope that "this school, with its happy union of ward and laboratory, university and local authority, drawing students and teachers alike from all parts of our Empire, and . . . from regions even more widely spread . . . [may] play an imperial rôle in the winning and dissemination of medical knowledge, in the relief of suffering ... and in enabling the doctors of all lands to come together in a task where all must be allies and helpers."

\section{Mechanisation of Industry}

IN an article in the Royal Jubilee number of Engineering published on May 3, Sir Richard Redmayne says that the mechanisation of industry tends to increase both the wages and the time available for leisure of the operatives, and thus increases their material welfare without the application of what are 
known as 'revolutionary methods'. He illustrates this progress by what is happening in the coal-mining industry. The hewing of coal by pick and filling it into a tub by shovel, in a more or less confined space, is work of the most arduous nature. The great expansion during recent years of mechanical coal cutters has made this work comparatively easy. In 1900 only 1.5 per cent of the British coal output and 25 per cent of the output of the United States was cut mechanically. In 1932 this had risen to 38 per cent in Britain and 68 per cent in the United States. In the Ruhr coalfield the mechanical pick has found great favour; in 1913 only $2 \cdot 2$ per cent was cut mechanically, now 90 per cent is, 84 per cent being cut by mechanical picks and 6 per cent by mechanical coal cutters. The transport of the cut coal from the coal face to the shaft bottom was almost as laborious as 'getting' the coal. Now, owing to the perfection of electrically actuated plant, not only is the haulage on the main roads carried out electrically, but in the secondary roads also it is replacing horses and ponies. So far as creation of wealth and increase of leisure and comfort of the mass of mankind are concerned, the engineer has taken a leading part. During the last 130 years, wages in coal-mining have risen $3 \cdot 2$ times and the daily time of labour has been decreased 37 per cent, the return on the capital remaining on the average stationary. The chief beneficiary under the system of mechanisation has been the manual worker. There is no doubt that the rationalisation of industry tends to decrease the number of employees, but Sir Richard Redmayne thinks that the lowering of the price of the commodity, its more effective distribution leading to the increase of new industries, together with the increase in wages and leisure creating an increased demand, will result in more than the absorption of the overplus of labour.

\section{Unemployment among Young Persons}

THE International Labour Office estimates that of about 25 million unemployed throughout the world, about one fourth, or 6-7 million, are young persons less than twenty-five years of age. In Great Britain the percentage between fourteen and twenty-four years old was 30.2 per cent in 1931, a figure which indicates the significance of the National Jubilee Trust inaugurated by the Prince of Wales. The corresponding figure for Switzerland in July 1934 was 15 per cent, but for Hungary in 1930 it reached 42 per cent ; in Italy in $1932,41.5$ per cent of the unemployed were between fifteen and twenty-five years of age. These figures indicate the quantitative significance of the discussions on unemployment among young persons at the International Labour Conference opening at Geneva on June 4. They do not, however, reveal the demoralising effects of prolonged unem. ployment, which are much more serious among young than among older persons. Steps already taken by various countries to deal with this position are indicated in a report prepared by the International Labour Office as a basis for the discussions. The report suggests that most of the measures to be taken to ameliorate unemployment among young persons call for pooling of experience rather than for the drafting of a convention. Particular stress is laid upon the raising of the school-leaving age to fifteen years; the creation of an increased number of technical schools; the organisation of vocational training centres in connexion with public employment agencies and the establishment of centres for recreation, physical training, etc.

\section{Molecular Structure of Dielectrics}

SrR Wilutam BragG chose the molecular structure of dielectrics as the subject of the twenty-sixth Kelvin Lecture delivered on May 2 to the Institution of Electrical Engineers. He pointed out that the properties of dielectrics depend on their composition and on the arrangement of their atoms and molecules. During the past twenty-five years, men of science have used $\mathrm{X}$-rays to study the structure of various substances, and engineers by other means have discovered many of the factors which govern the properties of dielectrics. It is now necessary that the two classes of workers should come together and pool their resources in making further advances. It is sometimes thought that $\mathrm{X}$-rays are only of use for examining the structure of crystals, but it has to be remembered that crystallisation is a property of all substances. The crystal is used to obtain electron maps of the image of a single molecule and these maps enable us to find out the electron densities in its various parts. It is possible in many molecules to measure the exact distance from atom to atom, and to determine the way in which they are linked together to form the molecules. This method of attack can be used even when the molecules are not so definite in shape as they are in a crystal. Sir William pointed out the analogies between the properties of proteins and those of dielectrics and laid stress on the recent work done at Leeds by Mr. W. T. Astbury. Once the basic theory of dielectrics is determined, rapid progress will be made in practical applications. It is fortunate that the researches in the pure science of atoms and molecules and the many technical investigations now being carried on are feeling their way towards each other.

\section{The New Commonwealth Society}

Accordrra to the annual report of the New Commonwealth for 1933-34, a clearer demarcation will in future be drawn between the research and propaganda activities of this organisation. Educa. tional and propaganda work will be undertaken by the New Commonwealth Society, which will continue to be subdivided into an international section and the various national sections. Brief reports of the activities of all these sections are included, which indicate the extent to which the scientific study of international affairs is being encouraged in this way. The scientific investigations hitherto carried out by the Research Bureau of the International Section will now be carried out by the New Commonwealth Institute. These activities are guided by an Advisory Research Committee, which includes among its 